\title{
miRNA profiling in metastatic renal cell carcinoma reveals a tumour-suppressor effect for miR-2 I 5
}

\section{NMA White ${ }^{1,2}$, HWZ Khella, ${ }^{1,3}$, J Grigull ${ }^{4}$, S Adzovic', YM Youssef', RJ Honey ${ }^{5}$, R Stewart ${ }^{5}$, KT Pace ${ }^{5}$, GA Bjarnason ${ }^{6}$, MAS Jewett ${ }^{7}$, AJ Evans ${ }^{2}, M_{\text {Gabril }}^{8}$ and GM Yousef ${ }^{*, 1,2}$}

'Department of Laboratory Medicine and the Keenan Research Centre in the Li Ka Shing Knowledge Institute of St. Michael's Hospital, Toronto, ON, Canada, M5B I W8; ${ }^{2}$ Department of Laboratory Medicine and Pathobiology, University of Toronto, Toronto, ON, Canada, M5S IA8; ${ }^{3}$ Institute of Medical Sciences, University of Toronto, Toronto, ON, Canada, M5S IA8; ${ }^{4}$ Department of Mathematics and Statistics, York University, Toronto, ON,

Canada, M3J IP3; ${ }^{5}$ Department of Surgery, St. Michael's Hospital, Toronto, ON, Canada, M5B I W8; ' Division of Medical Oncology and Hematology, Sunnybrook Health Sciences, Toronto, ON, Canada, M4N 3M5; ${ }^{7}$ Department of Surgery, Princess Margaret Hospital, Toronto, ON, Canada, M5G 2M9;

${ }^{8}$ Department of Pathology, London Health Sciences Center and University of Western Ontario, London, ON, Canada, N6A 5W9

BACKGROUND: Renal cell carcinoma (RCC) is the most common neoplasm of the adult kidney. Metastatic RCC is difficult to treat. The 5 -year survival rate for metastatic RCC is $\leqslant 10 \%$. Recently, microRNAs (miRNAs) have been shown to have a role in cancer metastasis and potential as prognostic biomarkers in cancer.

METHOD: We performed a miRNA microarray to identify a miRNA signature characteristic of metastatic compared with primary RCCs. We validated our results by quantitative real-time PCR. We performed experimental and bioinformatic analyses to explore the involvement of miR-2I 5 in RCC progression and metastasis.

RESULTS: We identified 65 miRNAs that were significantly altered in metastatic compared with primary RCCs. We validated our results by examining the expression of miR-10b, miR-126, miR-196a, miR-204 and miR-215, in two independent cohorts of patients. We showed that overexpression of miR-2I5 decreased cellular migration and invasion in an RCC cell line model. In addition, through gene expression profiling, we identified direct and indirect targets of miR-2I 5 that can contribute to tumour metastasis.

CONCLUSION: Our analysis showed that miRNAs are altered in metastatic RCCs and can contribute to kidney cancer metastasis through different biological processes. Dysregulated miRNAs represent potential prognostic biomarkers and may have therapeutic applications in kidney cancer.

British Journal of Cancer (201।) 105, 174I-1749. doi:10.1038/bjc.2011.401 www.bjcancer.com

Published online 27 October 2011

(C) 20II Cancer Research UK

Keywords: clear cell renal cell carcinoma; kidney cancer; metastasis; microRNA; miR-2I5; tumour markers

Renal cell carcinoma (RCC) is the most common neoplasm of the adult kidney. The overall incidence and mortality of RCC have increased over the past 20 years (Hollingsworth et al, 2006). Approximately 75-80\% RCC patients are diagnosed with the clear cell RCC (ccRCC) subtype (Capitanio et al, 2009). Although surgery is curative for localised disease, a significant proportion of patients relapse or metastasize. Metastatic RCC is difficult to treat. There have been many advances in RCC-targeted therapy in recent years, but unfortunately, despite these advances, the majority of patients ultimately still progress and succumb to the disease. The 5 -year survival rate for metastatic RCC is dismal at $\leqslant 10 \%$ (Motzer et al, 1996; Tsui et al, 2000). Predicting recurrences early can impact patient outcome as the likelihood of a favourable response to treatment is greater with limited metastatic burden (Antonelli et al, 2007).

*Correspondence: Dr GM Yousef; E-mail: yousefg@smh.ca

Note: Microarray expression data of this manuscript are submitted to Gene Expression Omnibus (GEO) (pending).

Received 2I June 20 I I; revised 25 August 20 I I; accepted I 3 September 201 I; published online 27 October $201 \mathrm{I}$
The process of metastasis is not well understood. Although quite a complex process, it can be summarised in a series of steps starting with local invasion, followed by intravasation, survival in the circulation, extravasation, initiation and maintenance of micrometastasis at a distant site and finally, vascularisation of the new tumour (Gupta and Massague, 2006). Recently, microRNAs (miRNAs), small non-protein-coding RNAs, have been reported to be involved in cancer progression and metastasis (Le et al, 2010; White et al, 2011b). MicroRNAs are approximately 19-25 nucleotides in length and have been found to negatively regulate gene expression at the post-transcriptional level by binding to target mRNAs leading to mRNA degradation or translational repression (He and Hannon, 2004).

Accumulating evidence shows that miRNAs have a role in the pathogenesis of RCC (Schaefer et al, 2010b). Recently, we along with others have reported dysregulation of miRNA expression in kidney cancer (Nakada et al, 2008; Jung et al, 2009; Juan et al, 2010; Youssef et al, 2011; White et al, 2011a). MicroRNAs have been shown to have an oncogenic effect on RCC (Chow et al, 2010a). As recently highlighted, miRNAs can contribute to RCC pathogenesis at different levels (White and Yousef, 2010). Several miRNAs are downstream effectors of the hypoxia-induced factor (HIF)-induced 
hypoxia response. In addition, certain miRNAs are regulated by von Hippel-Lindau in either a HIF-dependent or HIF-independent manner in RCC (Neal et al, 2010). Apart from the hypoxia pathway, recent experiments have shown that miRNAs can directly affect tumour proliferation and apoptosis through mechanisms that are yet to be identified (White et al, 2010a; Chow et al, 2010b).

miRNAs have also been shown to be involved in tumour progression and metastasis in colon (Huang et al, 2009), kidney (Heinzelmann et al, 2011) and other cancers. In a recent study, miRNAs were shown to stimulate breast cancer cell migration and invasion both in vitro and in vivo (Huang et al, 2008). In colon cancer, high miRNA expression was shown to promote cancer cell detachment, migration and invasion (Schimanski et al, 2009). Understanding the role miRNAs in metastasis will help elucidate this complex process and may lead to novel miRNA therapeutic targets for prevention or treatment of RCC metastasis.

MicroRNAs have also been shown to have clinical utility as cancer biomarkers (Arsanious et al, 2009; Metias et al, 2009; Schaefer et al, 2010a; Youssef et al, 2011). MicroRNAs were shown to be able to differentiate between primary lung cancer and lung metastasis (Barshack et al, 2010) and to be independent markers for poor prognosis in patients with lung and head and neck cancers (Childs et al, 2009; Gallardo et al, 2009).

In this study, we performed a miRNA microarray to analyse the expression profile of metastatic compared with primary ccRCC tumours. We validated our results by quantitative real-time PCR in two independent cohorts of patients. We also examined the role of one of the top dysregulated miRNAs, miR-215, in the pathogenesis of RCC metastasis. Our results showed that miR-215 is involved in cancer cellular migration and proliferation. We also identified a number of direct and indirect targets that are affected by overexpression of miR-215.

\section{PATIENTS AND METHODS}

\section{Patient specimens}

Patient specimens, including 28 fresh frozen and a total of 80 (both primary and metastatic) formalin-fixed paraffin-embedded (FFPE) tissues, were obtained from St Michael's Hospital, University Health Network, London Health Sciences Center and the Ontario Tumor Bank. Fresh specimens were collected immediately after resection, snap frozen in liquid nitrogen and stored at $-80^{\circ} \mathrm{C}$ until total RNA extraction. Samples were taken from areas with no haemorrhage or necrosis, and multiple sections were submitted from the same tumour to compensate for tumour heterogeneity. All diagnoses were confirmed by two pathologists. All procedures were carried out in accordance with St Michael's Research Ethics Board.

\section{Total RNA extraction and miRNA microarray}

In all, $2 \mathrm{mg}$ each of fresh-frozen primary and metastatic ccRCC tissues were used for nucleic acid isolation. Total RNA was extracted using the miRNeasy kit (Qiagen, Mississauga, ON, Canada) according to the manufacturer's protocol. Total RNA was extracted from cores of FFPE samples using the miRNeasy FFPE kit (Qiagen) according to the manufacturer's protocol. Total RNA concentrations were determined spectrophotometrically, and the quality of extracted RNA was assessed by electropherogram and gel analysis. Samples suitable for analysis were stored at $-80^{\circ} \mathrm{C}$.

Microarray analysis was performed on $4 \mu \mathrm{g}$ of total RNA obtained from 18 fresh-frozen primary ccRCC and 10 unmatched metastatic RCC tumours and was carried out using the $\mu$ Paraflo microfluidic technology, as per the manufacturer's protocol (LC Sciences, Houston, TX, USA). Hybridisation was performed overnight on a microfluidic chip. The array assessed all miRNA transcripts available in the version of the Sanger miRBase database (version 13.0) available at the time of the array. Post-hybridisation detection used fluorescence labelling with tag-specific Cy3 and Cy5 dyes. Hybridisation images were collected using a GenePix 4000B laser scanner (Molecular Device, Sunnyvale, CA, USA) and digitised using Array-Pro image analysis software (Media Cybernetics, Bethesda, MD, USA).

\section{Quantitative real-time RT-PCR}

Quantitative real-time PCR ( $\mathrm{qRT}-\mathrm{PCR}$ ) was used to measure miRNA expression using TaqMan MicroRNA assays (Applied Biosystems, Foster City, CA, USA) as described in our recent publications (Youssef et al, 2011). MicroRNA-specific reverse transcription was performed with $5 \mathrm{ng}$ total RNA using the TaqMan MicroRNA reverse transcription kit (Applied Biosystems) as recommended by the manufacturer for miR-10b, miR-126, miR-196a, miR-204 and miR-215. Quantitative real-time PCR was performed using the TaqMan microRNA assay kit on the Step-One Plus Real-Time PCR System (Applied Biosystems). Thermal cycling conditions were according to the manufacturer's fast protocol and all reactions were performed in duplicate. Relative expression was determined using the $\Delta \Delta \mathrm{C}_{\mathrm{T}}$ method and expression values were normalised to small nucleolar RNA, C/D box 44 (SNORD44, also known as RNU44), which has been shown to be a suitable reference gene (Chow et al, 2010a).

\section{Cell culture and miRNA transfection}

786-O and CAKI-1 RCC cells were obtained from American Type Culture Collection (ATCC, Manassas, VA, USA). 786-O cells were maintained in Dulbecco's modified Eagle's medium (DMEM) supplemented with $10 \%$ fetal calf serum (FCS). CAKI-1 cells were maintained in McCoy's 5A medium supplemented with 10\% FCS. All cells were maintained in $5 \% \mathrm{CO}_{2}$ at $37^{\circ} \mathrm{C}$.

Pre-miR precursors and anti-miR miR inhibitors (Applied Biosystems) were purchased for miR-215. Cells were transfected using siPORT NeoFX transfection agent (Ambion, Austin, TX, USA) as recommended by the manufacturer and described in previous publications (Chow et al, 2010a; White et al, 2010a,b). In brief, siPORT NeoFX transfection agent was diluted in Opti-MEM reduced serum media (Invitrogen, Carlsbad, CA, USA). Complexes were allowed to form for $10 \mathrm{~min}$ at room temperature. Precursor miRNA and miRNA inhibitors were diluted in Opti-MEM reduced serum media, combined with siPORT NeoFX, and incubated for $10 \mathrm{~min}$ at room temperature. Transfection complexes were added to the cell culture plate and overlayed with cell suspensions. Cells were then incubated at $37{ }^{\circ} \mathrm{C}$ and $5 \% \mathrm{CO}_{2}$. The final concentration of the miRNA precursor or inhibitor was $30 \mathrm{~nm}$.

\section{Wound-healing assay}

$786-\mathrm{O}$ cells were plated at $8.0 . \times 10^{4}$ cells per well in a 12 -well plate and transfected with miR-215, anti-miR-215 or co-transfected with miR-215 and its inhibitor as described above. Twenty-four hours later, the cell monolayer was wounded with a $200 \mu$ l pipette tip. Photomicrographs were taken at the time of wounding $(0 \mathrm{~h})$ and $11 \mathrm{~h}$ later. The rate of migration is displayed as the percentage of cell covered area (100 - percentage cell-free area) where percentage cell-free area is defined as ((cell-free area $_{11 \mathrm{~h}} /$ cell-free $\left.\operatorname{area}_{0 \mathrm{~h}}\right)$ $\times 100)$. The area was measured using the Image J Software (National Institutes of Health, Bethesda, MD, USA, http:// rsbweb.nih.gov/ij/). Cells were transfected in three separate transfections and each was analysed in triplicate. Three images were taken per 'wound'. A gridded coverslip was attached to the bottom of each well to ensure photomicrographs were being taken at the exact place each time. 


\section{Invasion assay}

The effect of miR-215 on cellular invasion was examined using BD BioCoat Matrigel Invasion Chamber (BD Biosciences, Bedford, MA, USA). 786-O cells were transfected with miR-215, anti-miR215 or co-transfected with miR-215 and its inhibitor. Twenty-four hours after transfection, cells were trypsinised and resuspended in DMEM supplemented with $0.5 \%$ FCS. A total of $5.0 \times 10^{4}$ cells were plated on the upper chamber. A normal growth medium, DMEM supplemented with $10 \%$ FCS, was added to the bottom chamber as a chemoattractant. Cells were allowed to invade for $22 \mathrm{~h}$. After incubation, non-invading cells were removed from the upper surface and cells on the lower surface were stained with Diff-Quick. Invading cells were counted by taking photomicrographs at $\times 40$ magnification in 3 fields. The experiment was performed in triplicate. Cell invasion is displayed as \% invasion (mean number of cells that invaded through Matrigel insert/mean number of cells that migrated through the control insert membrane).

\section{Cell proliferation assay}

Cellular proliferation was measured by both the 3-(4,5dimethylthiazol-2-yl)-2,5-diphenyltetrazolium bromide (MTT; Roche, Mississauga, ON, Canada) assay and cell counting. 786-O cells were plated at $6.0 \times 10^{3}$ cells per well in a 96-well plate and transfected with miR-215, anti-miR-215 or co-transfected with miR-215 and its inhibitor. Cells were incubated for 1-4 days after which $10 \mu \mathrm{l}$ of $5 \mathrm{mg} \mathrm{ml}^{-1}$ solution of MTT in phosphate-buffered saline was added and incubated for $4 \mathrm{~h}$ at $37^{\circ} \mathrm{C}$. The precipitate was then solubilised in $100 \mu \mathrm{l}$ solubilisation solution $(10 \%$ SDS in $0.01 \mathrm{M} \mathrm{HCl})$ and incubated at $37^{\circ} \mathrm{C}$ overnight. The absorbance of each well was measured at a wavelength of $550 \mathrm{~nm}$. Each test was repeated in triplicate. Cell proliferation was also assayed by cell counting. $786-\mathrm{O}$ cells were plated at $8.0 \times 10^{4}$ cells per well and were untransfected or transfected with miR-215, anti-miR-215 or cotransfected with miR-215 and its inhibitor. Cells were incubated for 1-4 days after which they were trypsinised and counted. Cells were counted in triplicate and repeated thrice.

\section{Western blot}

Cells were lysed $48 \mathrm{~h}$ after transfection using NETN lysis buffer $(0.5 \%$ Nonidet-P40, $100 \mathrm{~nm} \mathrm{NaCl}, 1 \mathrm{~mm}$ EDTA and $20 \mathrm{~mm}$ Tris-Cl ( $\mathrm{pH}$ 8.0) with protease inhibitor cocktail tablets (Roche)) and cleared by centrifugation at $21000 \mathrm{~g}$ for $10 \mathrm{~min}$ at $4{ }^{\circ} \mathrm{C}$. Protein concentrations were determined using the BCA protein assay reagent (Pierce Biotechnology, Rockford, IL, USA) using bovine serum albumin (BSA) as a standard.

Total cellular protein was separated in 12\% SDS-PAGE and transferred to a nitrocellulose membrane. The membrane was blocked with $3 \%$ BSA in TBST ( $150 \mathrm{~mm} \mathrm{NaCl}, 10 \mathrm{~mm}$ Tris- $\mathrm{HCl} \mathrm{pH}$ 8.0 and $0.1 \%(\mathrm{v} / \mathrm{v})$ Tween 20$)$ and incubated with anti-SIP1/ZEB2 primary antibody $\left(1 \mu \mathrm{g} \mathrm{ml}^{-1}\right.$, Abcam, Cambridge, MA, USA) diluted in blocking solution overnight at $4{ }^{\circ} \mathrm{C}$ with shaking. The membrane was then washed with TBST, incubated with anti-rabbit horseradish peroxidase-conjugated secondary antibody (Santa Cruz Biotechnology, Santa Cruz, CA, USA) diluted in blocking solution for $1 \mathrm{~h}$. Immune complexes were visualised using enhanced chemiluminescence and Hyperfilm (GE Healthcare, Piscataway, NJ, USA). Membranes were stripped and re-probed for $\beta$-actin $(1: 1000$, Cell Signalling Technology Inc., Danvers, MA, USA) as a loading control.

\section{$\mathrm{RT}^{2}$ tumour metastasis profiler assay}

CAKI-1 cells were transfected with miR-215 as described above and total RNA was collected after $48 \mathrm{~h}$. Genomic DNA contamination was eliminated using the RNase-Free DNase Set (Qiagen). For
PCR array experiments, the $\mathrm{RT}^{2}$ Profiler Tumor Metastasis PCR Array (SA Biosciences, Frederick, MD, USA) was used to simultaneously examine the levels of 89 genes associated with metastasis. In brief, cDNA was synthesised from $1 \mu \mathrm{g}$ total RNA using the $\mathrm{RT}^{2}$ First-Strand Kit (SA Biosciences) according to the manufacturer's protocol. Reaction mixtures were incubated at $42{ }^{\circ} \mathrm{C}$ for $15 \mathrm{~min}, 95^{\circ} \mathrm{C}$ for $5 \mathrm{~min}$ and held on ice until the PCR reaction. Changes in expression were measured by obtaining the threshold cycle and normalising to the average of five housekeeping genes. Fold change was calculated by $2^{(-\Delta \Delta \mathrm{Ct})}$ where $\Delta \Delta \mathrm{C}_{\mathrm{t}}=\left(\right.$ CAKI-1 cells transfected with miR-215 $\left(\mathrm{C}_{\mathrm{t}}\right.$ target $-\mathrm{C}_{\mathrm{t}}$ control $))-\left(\right.$ untransfected CAKI-1 cells $\left(\mathrm{C}_{\mathrm{t}}\right.$ target $-\mathrm{C}_{\mathrm{t}}$ control $)$ ).

\section{Statistical and clustering analysis}

LOWESS regression was applied to normalise raw quantitated intensities from the miRNA microarray analysis. Expression data from 875 miRNAs in 18 primary cancer and 10 (unpaired) metastatic cancer tissues were collated and filtered using Class Comparison in BRB ARRAYTools (version 3.8, developed by Dr Richard Simon and BRB-ArrayTools Development Team) and intensities were thresholded to 500. Using a false-discovery rate of $20 \%$ at a confidence level of $90 \%, 65$ miRNAs were identified as differentially expressed between metastatic and primary tissues. Significantly dysregulated miRNAs were clustered using the EisenLab Cluster and TreeView software (accessed through BRB ARRAYTools).

All other statistical analyses were performed using GraphPad Prism 5 Software (GraphPad, La Jolla, CA, USA). One-way ANOVA and post hoc multiple comparisons (Tukey's) were used to compare differences in mRNA expression, wound-healing and invasion assays. A $P$-value $<0.05$ was considered significant.

\section{Bioinformatics analysis}

miRNA target prediction analyses were performed using two programs; Target Combo 'Predicted Targets: Union' (Sethupathy et al, 2006) and miRecords (Xiao et al, 2009). A prediction was only included if it was detected by at least four programs.

\section{RESULTS}

\section{miRNA microarray}

Microarray analysis was performed on a total of 18 primary ccRCCs and 10 unmatched metastatic fresh-frozen tumours. In total, expression values for 875 miRNAs were reported. We identified 65 miRNAs that were significantly dysregulated in metastatic when compared with primary RCCs (Table 1). In all, 9 (14\%) had increased expression, whereas $56(86 \%)$ had decreased expression. miR-10b, miR-196a and miR-27b were the most downregulated, whereas miR-638, miR-1915 and miR-149* were the most upregulated in metastasis when compared with primary RCCs. A non-supervised 2D-cluster analysis was applied for all tumours and the 65 significantly dysregulated miRNAs (Figure 1).

We identified a miRNA signature that can reliably distinguish between primary and metastatic tumours. Interestingly, a subgroup of the primary tumours (C7, C11, C19 and C13) clustered under the metastatic arm with a group of miRNAs that follow the same pattern of expression (Figure 1, Group B), suggesting that they have an inherited aggressive signature. The dysregulated miRNAs can be clustered into three groups. Group A shows miRNA downregulation in metastasis when compared with primary (with the exception of one metastatic tumour). Group B shows a much more distinct upregulation of miRNAs in primary tumours and downregulation in both metastatic and the subgroup of primary tumours mentioned above. Group C shows miRNA 
Table I Significantly dysregulated miRNAs in metastatic vs primary clear cell renal cell carcinoma

\begin{tabular}{|c|c|c|}
\hline miRNA & Fold change metastatic/primary & $P$-value \\
\hline \multicolumn{3}{|l|}{ Upregulated } \\
\hline hsa-miR-638 & 2.380 & 0.0014239 \\
\hline hsa-miR-1915 & 2.271 & 0.0156326 \\
\hline hsa-miR-149* & 2.149 & 0.009039 \\
\hline hsa-miR-I469 & 2.116 & 0.0035103 \\
\hline hsa-miR-200c & 2.098 & 0.0138865 \\
\hline hsa-miR-720 & 1.947 & 0.0217099 \\
\hline hsa-miR-663 & 1.871 & $0.000487 \mid$ \\
\hline hsa-miR-498 & 1.449 & 0.0052433 \\
\hline hsa-miR-197 & 1.082 & 0.0132738 \\
\hline \multicolumn{3}{|l|}{ Downregulated } \\
\hline hsa-miR-IOb & 0.183 & 2.90E-06 \\
\hline hsa-miR-196a & 0.191 & 1.00E-07 \\
\hline hsa-miR-27b & 0.273 & ।.37E-05 \\
\hline hsa-miR-29c & 0.279 & 0.000174 \\
\hline hsa-miR-27a & 0.287 & 7.62E-05 \\
\hline hsa-miR-204 & 0.288 & 0.0060097 \\
\hline hsa-miR-195 & 0.289 & 3.87E-05 \\
\hline hsa-miR-30a & 0.296 & $3.90 \mathrm{E}-05$ \\
\hline hsa-miR-192 & 0.301 & $0.000327 \mid$ \\
\hline hsa-miR-98 & 0.315 & 0.0035068 \\
\hline hsa-miR-126 & 0.334 & 4.00E-07 \\
\hline hsa-miR-I 43 & 0.337 & 9.57E-05 \\
\hline hsa-miR-30e & 0.345 & 0.0003737 \\
\hline hsa-miR-I5a & 0.367 & 0.0004011 \\
\hline hsa-miR-26b & 0.386 & 5.70E-06 \\
\hline hsa-miR-2I5 & 0.423 & 0.0072108 \\
\hline hsa-miR-30a* & 0.426 & 0.0008579 \\
\hline hsa-miR-194 & 0.431 & 0.0009558 \\
\hline hsa-miR-I0a & 0.438 & 0.0100544 \\
\hline hsa-miR-200b & 0.440 & 0.0008925 \\
\hline hsa-miR-30d & 0.449 & $1.93 \mathrm{E}-05$ \\
\hline hsa-miR-145 & 0.455 & $0.000999 \mid$ \\
\hline hsa-miR-29a & 0.459 & 0.0015364 \\
\hline hsa-miR-30c & 0.466 & 0.0268396 \\
\hline hsa-miR-455-3p & 0.467 & 0.0005517 \\
\hline hsa-miR-181a & 0.472 & 0.0003763 \\
\hline hsa-let-7e & 0.489 & 0.0001903 \\
\hline hsa-let-7g & 0.492 & 4.00E-07 \\
\hline hsa-miR-20a & 0.500 & 0.0015265 \\
\hline hsa-miR-122 & 0.517 & 0.0425357 \\
\hline hsa-miR-24 & 0.525 & 0.0002439 \\
\hline hsa-miR-374b & 0.534 & 0.0059959 \\
\hline hsa-miR-30b & 0.543 & 0.029005 \\
\hline hsa-let-7f & 0.559 & $2.45 \mathrm{E}-05$ \\
\hline hsa-miR-|5|-5p & 0.568 & 0.0009097 \\
\hline hsa-miR-36I-5p & 0.582 & 4.29E-05 \\
\hline hsa-miR-17 & 0.586 & 0.009408 \\
\hline hsa-miR-18Ib & 0.590 & 0.0042813 \\
\hline hsa-miR-106a & 0.592 & 0.0043882 \\
\hline hsa-let-7d & 0.618 & $2.81 \mathrm{I}-05$ \\
\hline hsa-miR-I52 & 0.627 & 0.0048502 \\
\hline hsa-miR-26a & 0.650 & $0.0008 \mid 54$ \\
\hline hsa-let-7a & 0.659 & 0.0004721 \\
\hline hsa-miR-103 & 0.675 & 0.0256554 \\
\hline hsa-miR-30e* & 0.683 & 0.0273815 \\
\hline hsa-let-7c & 0.689 & 0.0004237 \\
\hline hsa-let-7i & 0.701 & 0.0025987 \\
\hline hsa-miR-107 & 0.702 & 0.0296412 \\
\hline hsa-miR-I06b & 0.707 & 0.0337003 \\
\hline hsa-miR-29b & 0.728 & 0.0399051 \\
\hline hsa-miR-23b & 0.739 & 0.042895 \\
\hline hsa-miR-130a & 0.752 & 0.0037552 \\
\hline hsa-miR-15I-3p & 0.760 & 0.0092847 \\
\hline hsa-miR-28-5p & 0.771 & 0.0355917 \\
\hline hsa-let-7b & 0.779 & 0.0097388 \\
\hline hsa-miR-200a & 0.822 & 0.0540674 \\
\hline
\end{tabular}

Abbreviation: miRNA = microRNA. downregulation in primary and upregulation in metastatic tumours.

\section{Quantitative real-time PCR validation}

On the basis of miRNA microarray results, we experimentally verified expression levels of five miRNAs, miR-10b, miR-126, miR-196a, miR-204 and miR-215, in two independent cohorts of tissues with the 'gold-standard' qRT-PCR using miRNA-specific TaqMan probes. First, we verified our results on 18 primary and 10 metastatic unmatched fresh-frozen RCC tissues. As shown in Figure 2A, all five miRNAs showed decreased expression in metastatic when compared with primary RCCs. These results are comparable to expression levels of the microarray analysis. We also validated our results on a separate cohort of 40 primary RCCs and 40 unmatched RCC metastatic FFPE tissues. All miRNAs showed decreased expression in the metastatic tumours, thus further validating both the microarray analysis and the fresh-tissue PCR analysis. A representative amplification plot of miR-215 expression is shown in Figure 2B.

\section{Bioinformatics analysis}

We further explored the role of these dysregulated miRNAs in RCC tumour progression and metastasis through bioinformatics analysis. Interestingly, a literature search showed that many of the miRNAs that we found dysregulated in metastatic RCCs have also been reported to be altered in tumour progression and metastasis of other cancers (Table 2). This implies the presence of common mechanisms/pathways that are used by multiple malignancies to achieve a metastatic phenotype. We also performed target prediction analysis for these miRNAs. As shown in Supplementary Table 1, a number of critical molecules that are documented to have a role in metastasis are among the predicted targets of miRNAs, namely MMP3, TIMP3 and SIP1/ZEB2.

\section{miR-215 overexpression slows cellular migration}

To investigate the role of miRNAs in tumour metastasis, we chose to further characterise the effect of miR-215 in a RCC cell line model. Our analysis showed that miR-215 was among the most significantly downregulated miRNAs in metastatic when compared with primary RCC tumours (Table 1 ). In addition, miR-215 was dysregulated in the vast majority of metastatic tumours analysed (downregulation was reported in $90 \%$ samples in the microarray, $100 \%$ fresh frozen samples and $87 \%$ FFPE samples analysed by qRT-PCR, data not shown). miR-215 was also chosen for further characterisation based on its reported dysregulation in other cancers, its known biological effect in other cancers and the fact that one of its targets, SIP1/ZEB2, has been shown to be involved in epithelial-to-mesenchymal transition.

We analysed the effect of miR-215 on cellular migration by a wound-healing assay. Representative microphotographs of the assay are shown in Figure $3 \mathrm{~A}$. When the 786-O kidney cancer cell line, which has no endogenous miR-215 expression, was transfected with miR-215, cells migrated significantly slower than did control cells (70 vs $90 \%$ cell covered area, respectively, $P<0.05$ ), cells transfected with the miR-215 inhibitor (70 vs 86\% cell covered area, respectively, $P<0.05)$ and cells transfected with a combination of the miR-215 and its inhibitor (70 vs $94 \%$ cell covered area, respectively, $P<0.05$; Figure $3 \mathrm{~B}$ ), indicating that miR-215 has a negative effect on cellular migration.

\section{miR-215 decreases cellular invasion}

The effect of miR-215 on cell invasion was measured through a cellular invasion assay as described in the 'Patients and methods' section. 786-O cells were transfected with miR-215, its inhibitor, or 


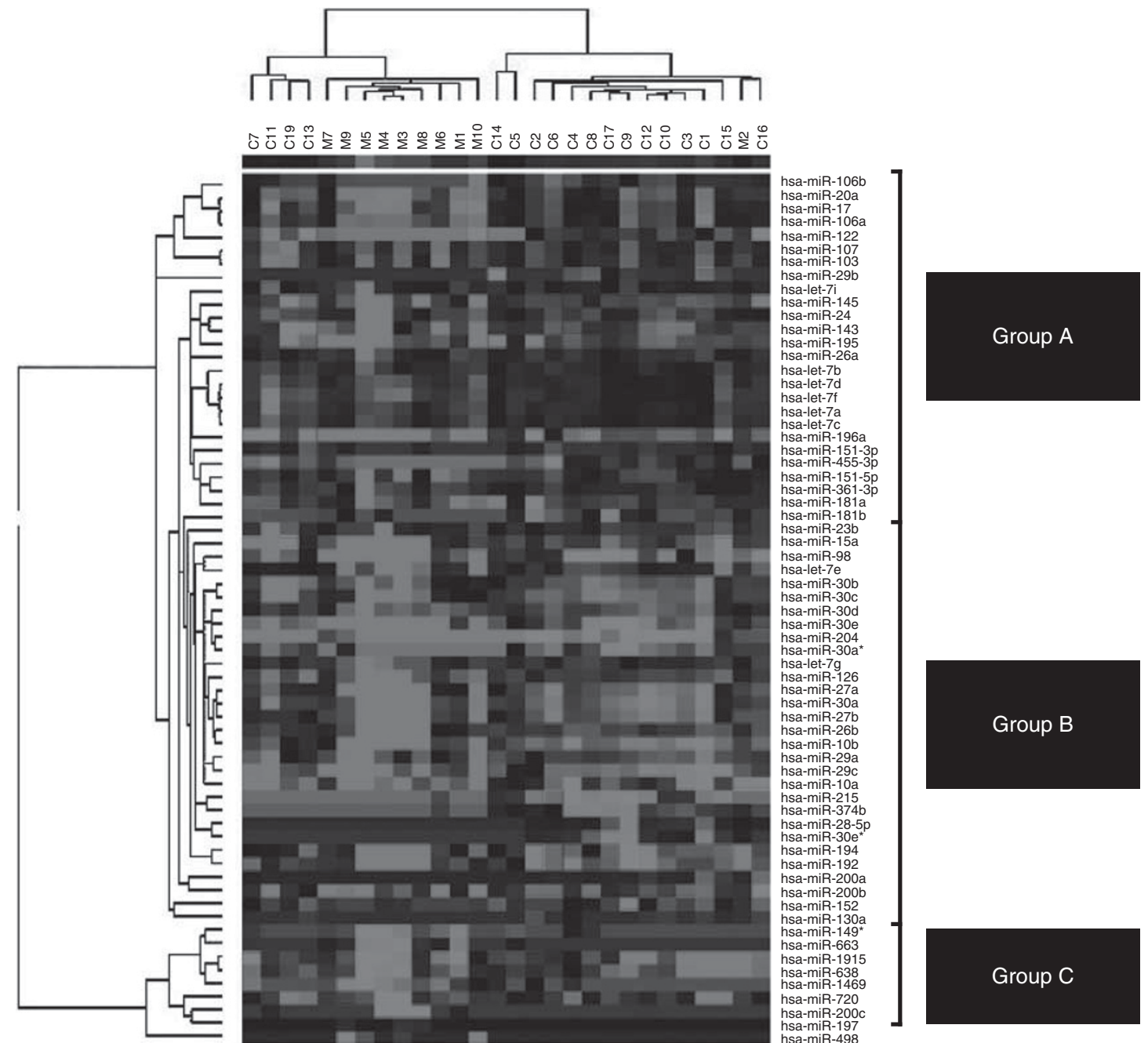

Figure I Heat map showing the top statistically significant $(P<0.05)$ altered miRNAs in metastatic $(m)$ compared with primary $(c)$ ccRCC. A nonsupervised analysis was applied to 10 metastatic RCC and 18 primary ccRCC profiles for 65 statistically significant miRNAs. Intensity profiles are displayed as a tree on the top and miRNA reporters are displayed on the right of the heat map with the tree on the left. Upregulation in metastasis is depicted as red squares and downregulation as green squares. The colour reproduction of this figure is available at the British Journal of Cancer online.

a combination of both and allowed to invade through Matrigel for $22 \mathrm{~h}$. The number of cells that invaded was compared with controluntransfected cells. Cells that were transfected with miR-215 showed a decrease in cellular invasion (Figure 3C). Cells that were transfected with either the anti-miR-215 or a combination of miR-215 and its inhibitor showed invasion levels that were comparable to control cells.

\section{miR-215 affects cell proliferation}

To see the effect of miR-215 on cellular proliferation, we performed an MTT assay. 786-O cells were transfected with miR-215 or anti-miR-215 and cell proliferation was measured over 4 days. Increased miRNA expression was sustained for at least 5 days after transfection (data not shown). Cells transfected with miR-215 showed a slight decrease in cell proliferation when compared with control cells (Supplementary Figure 1A). To confirm these results, we assayed cell proliferation by cell counting. The RCC cells that were transfected with miR-215 showed decreased cell growth compared with untransfected cells (Supplementary Figure 1B). To see the specific effects of increased miR-215 expression on cell cycle, we analysed cell distribution by propidium iodide staining. When cells were transfected with miR215 , there was a slight increase in the number of transfected cells in the G1 phase (49\% vs 51\%) and a decrease in cells in the G2/M phase (22\% vs $21 \%$ ) phase (data not shown).

\section{miR-215 can directly target SIP1/ZEB2}

To explore the mechanism by which miR-215 negatively affects cell migration and invasion, we examined the effect of miR-215 transfection on SIP1/ZEB2 (smad-interacting protein 1/zinc-finger E-box-binding homeobox 2) protein expression, which is a direct predicted target of miR-215 (Supplementary Table 1). SIP1/ZEB2 is a member of the $\delta \mathrm{EF}-1$ family of zinc nuclear factors and represses E-cadherin. It has been shown to be involved in epithelial-tomesenchymal transition, and recent evidence showed that its expression can be regulated by miRNAs (Park et al, 2008). 786-O cells were transfected with miR-215, anti-miR-215 or a combination of both and SIP1/ZEB2 protein expression was examined. There was a decrease in SIP1/ZEB2 protein expression when cells were transfected with miR-215 (Figure 3D), confirming that SIP1/ ZEB2 is a direct target of miR-215. There was no change in SIP1/ ZEB2 expression when cells were transfected with the miR-215 
inhibitor, a combination of the miR-215 and its inhibitor, or scramble miRNA.

\section{The effect of miR-215 on downstream targets involved in metastasis}

We performed target prediction analysis to identify potential targets of miR-215 that can affect metastasis as shown in Supplementary Table 1. To identify potential metastasis-related

A
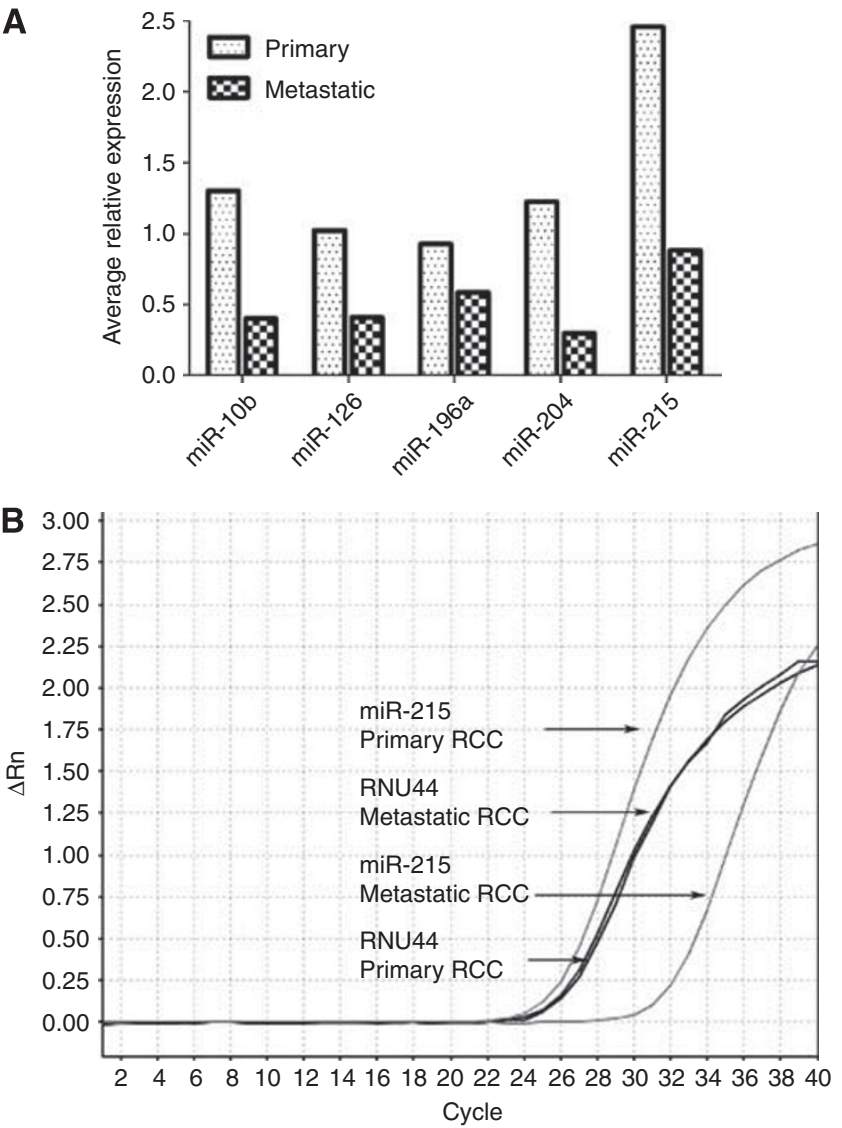

Figure 2 Quantitative real-time PCR validation of miRNA microarray analysis. (A) Bar graph showing average expressions of miR- I0b, miR- I26, miR-196a, miR-204 and miR-2I5 were decreased in metastatic when compared with primary RCC. (B) Representative real-time PCR amplification plot showing miR-2I5 downregulation in metastatic compared with primary RCCs. pathways that can be regulated by miR-215, the effect of miR-215 transfection on the expression levels of a panel of 89 genes that are documented to be altered in metastasis was measured in a kidney cancer cell line model using a 'Tumor Metastasis PCR Array.' We identified 27 genes that had a fold regulation \pm 1.2 upon miR-215 transfection (Table 3). Interestingly, two of these genes, EPH receptor B2 (EBHB2) and nuclear receptor subfamily 4, group A, member 4 (NR4A3), which both show gene downregulation $(-1.043$ and -1.257 , respectively), are direct predicted targets of miR-215 and are involved in cellular proliferation. Other genes involved in cell proliferation that had decreased expression were $M Y C, I G F 1$ and SMAD2. We also found changes in gene expression in cell adhesion genes, including decreased cadherin 6 and 11 and $M M P 3$ and HPSE.

\section{DISCUSSION}

In this study, we identified a miRNA signature for metastatic compared with primary RCCs. The majority $(86 \%)$ of the miRNAs identified were downregulated. This trend of miRNA downregulation in metastasis has also been reported for other cancers (Zhang et al, 2010). An interesting observation is that a number of miRNAs that were reported to be downregulated in primary RCCs (White et $a l, 2011$ a) were reported to be further downregulated in metastatic RCCs, suggesting that these miRNAs may contribute to both the initiation and progression of RCC and that their progressive downregulation may have a further role in the development of metastatic RCC. For example, miR-204 was reported to be downregulated in primary RCCs and was found to be further downregulated in the current analysis.

Although we identified many unique miRNAs that are significantly dysregulated in metastatic RCCs, a number of miRNAs identified were also reported in other metastatic cancers. For example, miR-122 and miR-126 (Budhu et al, 2008), as well as miR10b (Malzkorn et al, 2010), have been reported to be downregulated in metastasis when compared with primary tumours. These miRNAs may have a role in 'common' progression/metastatic pathways that are used by a number of different cancers.

The miRNAs identified in our study have the potential to serve as prognostic markers in RCCs. Recently, it was shown that tumour-associated circulating miRNAs are elevated in the blood of breast cancer patients and they were associated with tumour progression (Roth et al, 2010). MicroRNAs have also been shown to be potential urinary markers for bladder cancer (Hanke et al, 2009). In addition, miRNAs were proved to be very stable and resistant to RNAse activity, extreme $\mathrm{pH}$ and temperature in body fluids (Chen et al, 2008; Hanke et al, 2009). The use of serum and urine markers is very attractive for RCC patients as the kidney is in direct contact with blood and urine.

Table 2 The involvement of miRNAs dysregulated in metastatic renal cell carcinoma in the progression and metastasis of other cancers and their biological roles and targets

\begin{tabular}{|c|c|c|c|c|}
\hline microRNA & Dysregulation & Cancer & Biological function & Targets \\
\hline miR-204 & Down & HNSCC & Adhesion, cell migration and invasion & SHP2 \\
\hline miR-196a & Up & Colorectal & Cell migration and invasion & HoxA7, HoxB8, HoxC8, HoxD8 \\
\hline \multirow[t]{3}{*}{ miR-10b } & Up & Breast & Cell migration and invasion & Hox DI0, RhoC (through HoxDI0) \\
\hline & Up & Oesophageal & Cell motility and invasion & KLF4 \\
\hline & Up & Glioma & Cell invasion & uPAR, RhoC (through HoxD|0) \\
\hline miR-663 & Down & Gastric & Prevents cell proliferation & Cyclin B \\
\hline \multirow[t]{3}{*}{ miR- 122} & Down & Liver & Decreased viability & \\
\hline & Down & Liver & Metastatic progression & ADAMI7 \\
\hline & Down & Liver & Migration and invasion & \\
\hline miR-98 & Up & Lung & & FUSI \\
\hline miR-29c & Down & Nasopharengyl & Invasion & Extracellular matrix proteins \\
\hline
\end{tabular}

Abbreviations: HNSCC $=$ head and neck squamous cell carcinoma; miRNA = microRNA. 
A

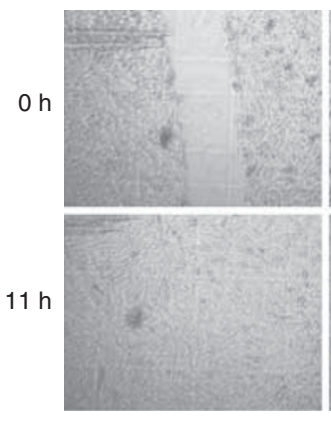

miR-215

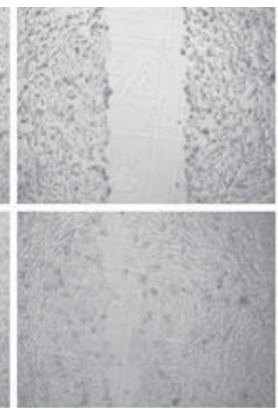

anti-miR-215

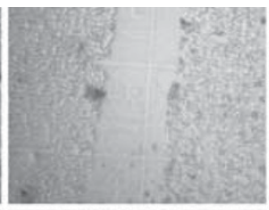

miR-215 + anti-miR-215

C

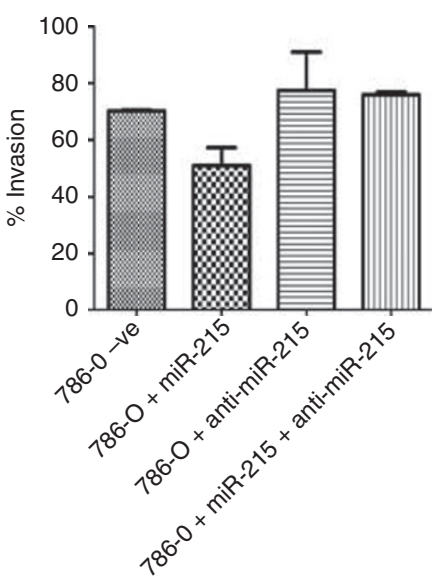

D

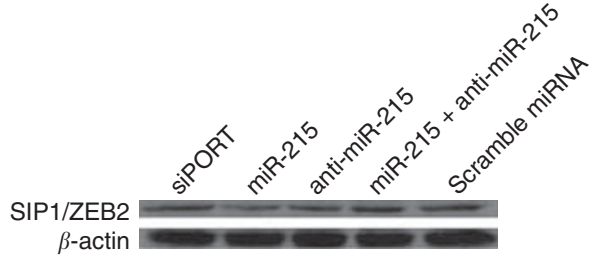

B

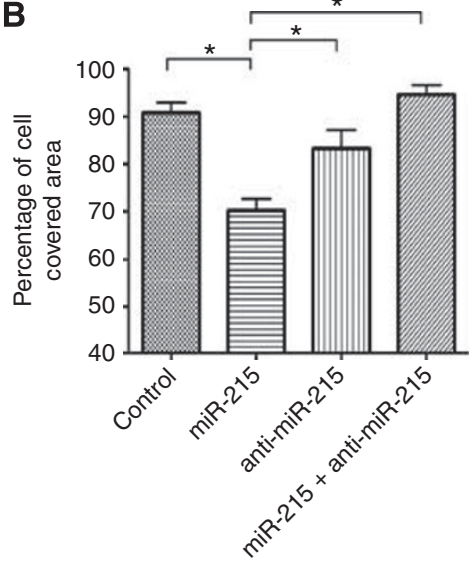

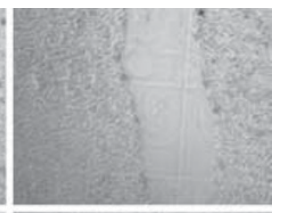

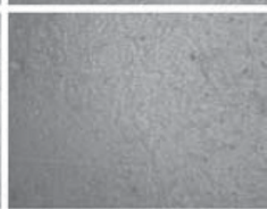

Figure 3 miR-2I 5 has a negative effect on cellular migration and invasion. (A) Representative photomicrographs of untransfected 786-O kidney cancer cells (Control) and 786-O cells transfected with miR-2I5, anti-miR-2I5 or a combination of both at the time of wounding ( $0 \mathrm{~h}$ ) and $\mid \mathrm{I} \mathrm{h}$ later. All photomicrographs were taken at $\times 40$ magnification. (B) Cell migration was measured by comparing the cell covered area at the time of wounding ( $0 \mathrm{~h}$ ) and II hours later $(\mathrm{I} \mid \mathrm{h})$. Cells transfected with miR-2 15 (70\% cell covered area) showed a significantly slower migration rate than did control cells ( $90 \%)$, cells transfected with anti-miR-2I5 (86\%) and cells transfected with a combination of miR-2I5 and anti-miR-2I5. (C) 786-O cells were transfected with miR-215, anti-miR-215 or a combination of miR-215 and its inhibitor. Cells transfected with miR-215 showed decreased cellular invasion after $22 \mathrm{~h}$ compared with those transfected with anti-miR-2I5 or a combination of miR-2I5 and its inhibitor. (D) 786-O cells were transfected with transfection reagent alone, miR-215, anti-miR-215, a combination of miR-2I5 and its inhibitor, or a random sequence miRNA, and the expression of SIPI/ZEB2 was examined by western blot analysis. There was decreased protein expression in cells that were transfected with miR-2I5. All other conditions showed no change in protein expression. $\beta$-Actin was used as a loading control. $* P<0.05$.

In tumour progression and metastasis, miRNAs can act as oncogenes or tumour suppressors depending on their target genes. Gene regulation by miRNAs is not a simple process as they can have both direct and indirect targets. Direct targets of miRNAs can be affected at the mRNA level as a result of mRNA degradation or at the protein level by translation inhibition. Indirect targets of miRNAs can be downstream effector molecules of miRNA targets.

We found that increased expression of miR-215 decreased cell migration in RCC cells. This may be attributed to the effect of miR-215 on the expression of SIP1/ZEB2. SIP1/ZEB2 is a predicted direct target of miR-215 and we showed that upon transfection with miR-215, protein expression of this target was decreased. SIP1/ZEB2 represses E-cadherin and its role in epithelial-tomesenchymal transition and more recently, the involvement of miRNAs in this interaction has been documented in the literature (Korpal and Kang, 2008). In a recent study, miR-192/215 was shown to repress SIP1/ZEB2 translation (Wang et al, 2010). Furthermore, Braun et al (2008) found that miR-192 and miR-215 had an effect on cellular adhesion and induced cell detachment. In addition, our metastatic gene profiler assay identified a number of genes that are involved in cell adhesion to be affected by miR-215, including cadherin 1 and integrin. These may be direct or indirect targets of miR-215. Through our metastatic gene profiling assay, we also identified a number of genes that are involved in the degradation of the extracellular matrix and are affected by increased miR-215 expression, including MMP7 and MMP13. We also showed that miR-215 dysregulation directly affects cellular invasion in a cell line model. These data together support the role of miR-215 in tumour progression and metastasis. In addition to their clinical implications as prognostic markers, miRNA dysregulated in RCC metastasis reveals a new dimension to our understanding to the regulatory mechanisms of tumour progression and metastasis (Sotiropoulou et al, 2009; White and Yousef, 2010; White et al, 2011b). MicroRNAs also represent attractive therapeutic targets.

We showed that miR-215 expression was decreased in RCC metastatic samples when compared with primary RCC tissues in both fresh-frozen and FFPE tissues (Figure 2). miR-215 has also been shown to be downregulated in primary RCCs (White et al, 2011a) and colon cancers (Braun et al, 2008). The link between miR-215 and cell proliferation is currently being investigated and results suggest that miR-192 and miR-215 can induce cell-cycle arrest by increasing levels of p21 (Braun et al, 2008). Furthermore, miR-192 and miR-215 have been shown to be involved in chemosensitivity, and recent data suggest that expression levels may be a predictive marker for 5-fluoruracil treatment in colon cancer patients (Boni et al, 2010). 
Table 3 Differential gene expression of metastasis-related genes upon miR-215 overexpression in kidney cancer cell lines

\begin{tabular}{|c|c|c|c|c|}
\hline Cell process & Unigene & Symbol & Description & Fold regulation \\
\hline Cell adhesion & $\begin{array}{l}\text { Hs. } 461086 \\
\text { Hs. I I } 6471 \\
\text { Hs. } 171054 \\
\text { Hs.524484 } \\
\text { Hs.449909 } \\
\text { Hs.534797 }\end{array}$ & $\begin{array}{l}\text { CDHI } \\
\text { CDHII } \\
\text { CDH6 } \\
\text { ITGA7 } \\
\text { RPSA } \\
\text { CTNNAI }\end{array}$ & $\begin{array}{l}\text { Cadherin I, type 1, E-cadherin (epithelial) } \\
\text { Cadherin II, type 2, OB-cadherin (osteoblast) } \\
\text { Cadherin 6, type 2, K-cadherin (fetal kidney) } \\
\text { Integrin, } \alpha 7 \\
\text { Ribosomal protein SA } \\
\text { Catenin (cadherin-associated protein), } \alpha 1,102 \mathrm{kDa}\end{array}$ & $\begin{array}{r}-1.549 \\
1.522 \\
2.633 \\
-1.467 \\
-1.503 \\
1.200\end{array}$ \\
\hline Extracellular matrix & $\begin{array}{l}\text { Hs.2936 } \\
\text { Hs.375I } 29 \\
\text { Hs.2256 } \\
\text { Hs.644633 } \\
\text { Hs.44227 }\end{array}$ & $\begin{array}{l}\text { MMPI3 } \\
\text { MMP3 } \\
\text { MMP7 } \\
\text { TIMP3 } \\
\text { HPSE }\end{array}$ & $\begin{array}{l}\text { Matrix metallopeptidase } 13 \text { (collagenase 3) } \\
\text { Matrix metallopeptidase } 3 \text { (stromelysin I, progelatinase) } \\
\text { Matrix metallopeptidase } 7 \text { (matrilysin, uterine) } \\
\text { TIMP metallopeptidase inhibitor } 3 \\
\text { Heparanase }\end{array}$ & $\begin{array}{r}1.270 \\
-1.394 \\
1.461 \\
1.379 \\
-1.251\end{array}$ \\
\hline Cell-cycle regulation & Hs.202453 & MYC & V-myc myelocytomatosis viral oncogene homolog (avian) & -1.200 \\
\hline Cell proliferation & $\begin{array}{l}\text { Hs. } 160562 \\
\text { Hs.25I } 526 \\
\text { Hs.478275 } \\
\text { Hs.523329 } \\
\text { Hs.279522 } \\
\text { Hs.494I } 78 \\
\text { Hs.5I } 4451 \\
\text { Hs. } 16041 \text { I } \\
\text { Hs. } 155942 \\
\text { Hs.208229 } \\
\text { Hs. } 165950\end{array}$ & $\begin{array}{l}\text { IGFI } \\
\text { CCL7 } \\
\text { TNFSFIO } \\
\text { EPHB2 } \\
\text { NR4A3 } \\
\text { RORB } \\
\text { SSTR2 } \\
\text { TSHR } \\
\text { TRPMI } \\
\text { KISSRI } \\
\text { FGFR4 }\end{array}$ & $\begin{array}{l}\text { Insulin-like growth factor (somatomedin C) } \\
\text { Chemokine (C-C motif) ligand } 7 \\
\text { Tumour necrosis factor (ligand) superfamily, member } 10 \\
\text { EPH receptor B2 } \\
\text { Nuclear receptor subfamily } 4 \text {, group A, member } 3 \\
\text { RAR-related orphan receptor B } \\
\text { Somatostatin receptor } 2 \\
\text { Thyroid-stimulating hormone receptor } \\
\text { Transient receptor potential cation channel, subfamily M, member I } \\
\text { KISSI receptor } \\
\text { Fibroblast growth factor receptor } 4\end{array}$ & $\begin{array}{r}-1.484 \\
-1.598 \\
2.126 \\
-1.043 \\
-1.257 \\
1.573 \\
-1.377 \\
1.370 \\
1.252 \\
-1.192 \\
-1.197\end{array}$ \\
\hline Transcription factor & Hs. I 2253 & SMAD2 & SMAD family member 2 & -1.232 \\
\hline $\begin{array}{l}\text { Other genes } \\
\text { related to } \\
\text { metastasis }\end{array}$ & $\begin{array}{l}\text { Hs. } 143212 \\
\text { Hs. } 632466 \\
\text { Hs. } 95008 \\
\text { Hs. } 444986\end{array}$ & $\begin{array}{l}\text { CST7 } \\
\text { CTSK } \\
\text { KISSI } \\
\text { METAP2 }\end{array}$ & $\begin{array}{l}\text { Cystatin F (leukocystatin) } \\
\text { Cathepsin K } \\
\text { KISS-I metastasis-suppressor } \\
\text { Methionyl aminopeptidase } 2\end{array}$ & $\begin{array}{r}-1.195 \\
1.224 \\
1.206 \\
-1.387\end{array}$ \\
\hline
\end{tabular}

Abbreviation: miRNA = microRNA.

In conclusion, we identified a miRNA signature that characterises metastatic RCCs from primary RCCs. We also showed that miR-215 is a tumour suppressor in RCC metastasis. Through experimental analysis, we showed that overexpression of miR-215 in an RCC cell line model can affect metastatic potential through cellular migration and invasion. Through target prediction analysis and gene expression profiling, we also identified potential mechanisms and pathways in which miR-215 can have this effect. A better understanding of the mechanisms of metastasis will allow for the development of potential future therapeutic targets for RCC patients.

\section{REFERENCES}

Antonelli A, Cozzoli A, Zani D, Zanotelli T, Nicolai M, Cunico SC, Simeone C (2007) The follow-up management of non-metastatic renal cell carcinoma: definition of a surveillance protocol. BJU Int 99(2): $296-300$

Arsanious A, Bjarnason GA, Yousef GM (2009) From bench to bedside: current and future applications of molecular profiling in renal cell carcinoma. Mol Cancer 8: 20

Barshack I, Lithwick-Yanai G, Afek A, Rosenblatt K, Tabibian-Keissar H, Zepeniuk M, Cohen L, Dan H, Zion O, Strenov Y, Polak-Charcon S, Perelman M (2010) MicroRNA expression differentiates between primary lung tumors and metastases to the lung. Pathol Res Pract 206(8): 578-584

Boni V, Bitarte N, Cristobal I, Zarate R, Rodriguez J, Maiello E, GarciaFoncillas J, Bandres E (2010) miR-192/miR-215 influence 5-fluorouracil resistance through cell cycle-mediated mechanisms complementary to its post-transcriptional thymidilate synthase regulation. Mol Cancer Ther 9(8): $2265-2275$

Braun CJ, Zhang X, Savelyeva I, Wolff S, Moll UM, Schepeler T, Orntoft TF, Andersen CL, Dobbelstein M (2008) p53-responsive micrornas 192 and 215 are capable of inducing cell cycle arrest. Cancer Res 68(24): $10094-10104$

\section{ACKNOWLEDGEMENTS}

This study was supported by grants from the Canadian Cancer Society (CCS grant no. 20185), the Ministry of Research and Innovation of the Government of Ontario, the Kidney Foundation of Canada and the Cancer Research Society.

Supplementary Information accompanies the paper on British Journal of Cancer website (http://www.nature.com/bjc)
Budhu A, Jia HL, Forgues M, Liu CG, Goldstein D, Lam A, Zanetti KA, Ye QH, Qin LX, Croce CM, Tang ZY, Wang XW (2008) Identification of metastasis-related microRNAs in hepatocellular carcinoma. Hepatology 47(3): $897-907$

Capitanio U, Cloutier V, Zini L, Isbarn H, Jeldres C, Shariat SF, Perrotte P, Antebi E, Patard JJ, Montorsi F, Karakiewicz PI (2009) A critical assessment of the prognostic value of clear cell, papillary and chromophobe histological subtypes in renal cell carcinoma: a population-based study. BJU Int 103(11): 1496-1500

Chen X, Ba Y, Ma L, Cai X, Yin Y, Wang K, Guo J, Zhang Y, Chen J, Guo X, Li Q, Li X, Wang W, Zhang Y, Wang J, Jiang X, Xiang Y, Xu C, Zheng P, Zhang J, Li R, Zhang H, Shang X, Gong T, Ning G, Wang J, Zen K, Zhang J, Zhang CY (2008) Characterization of microRNAs in serum: a novel class of biomarkers for diagnosis of cancer and other diseases. Cell Res 18(10): $997-1006$

Childs G, Fazzari M, Kung G, Kawachi N, Brandwein-Gensler M, McLemore M, Chen Q, Burk RD, Smith RV, Prystowsky MB, Belbin TJ, Schlecht NF (2009) Low-level expression of microRNAs let-7d and miR-205 are prognostic markers of head and neck squamous cell carcinoma. Am J Pathol 174(3): $736-745$ 
Chow TF, Mankaruos M, Scorilas A, Youssef Y, Girgis A, Mossad S, Metias S, Rofael Y, Honey RJ, Stewart R, Pace KT, Yousef GM (2010a) The miR-17-92 cluster is over expressed in and has an oncogenic effect on renal cell carcinoma. J Urol 183(2): 743-751

Chow TF, Mankaruos M, Scorilas A, Youssef Y, Girgis A, Mossad S, Metias S, Rofael Y, Honey RJ, Stewart R, Pace KT, Yousef GM (2010b) The miR$17-92$ cluster is over expressed in and has an oncogenic effect on renal cell carcinoma. J Urol 183(2): 743-751

Gallardo E, Navarro A, Vinolas N, Marrades RM, Diaz T, Gel B, Quera A, Bandres E, Garcia-Foncillas J, Ramirez J, Monzo M (2009) miR-34a as a prognostic marker of relapse in surgically resected non-small-cell lung cancer. Carcinogenesis 30(11): $1903-1909$

Gupta GP, Massague J (2006) Cancer metastasis: building a framework. Cell 127(4): $679-695$

Hanke M, Hoefig K, Merz H, Feller AC, Kausch I, Jocham D, Warnecke JM, Sczakiel G (2009) A robust methodology to study urine microRNA as tumor marker: microRNA-126 and microRNA-182 are related to urinary bladder cancer. Urol Oncol 28(6): 655-661

He L, Hannon GJ (2004) MicroRNAs: small RNAs with a big role in gene regulation. Nat Rev Genet 5(7): 522-531

Heinzelmann J, Henning B, Sanjmyatav J, Posorski N, Steiner T, Wunderlich H, Gajda MR, Junker K (2011) Specific miRNA signatures are associated with metastasis and poor prognosis in clear cell renal cell carcinoma. World J Urol 29(3): 367-373

Hollingsworth JM, Miller DC, Daignault S, Hollenbeck BK (2006) Rising incidence of small renal masses: a need to reassess treatment effect. J Natl Cancer Inst 98(18): 1331 - 1334

Huang Q, Gumireddy K, Schrier M, le SC, Nagel R, Nair S, Egan DA, Li A, Huang G, Klein-Szanto AJ, Gimotty PA, Katsaros D, Coukos G, Zhang L, Pure E, Agami R (2008) The microRNAs miR-373 and miR-520c promote tumour invasion and metastasis. Nat Cell Biol 10(2): 202-210

Huang ZM, Yang J, Shen XY, Zhang XY, Meng FS, Xu JT, Zhang BF, Gao HJ (2009) MicroRNA expression profile in non-cancerous colonic tissue associated with lymph node metastasis of colon cancer. J Dig Dis 10(3): $188-194$

Juan D, Alexe G, Antes T, Liu H, Madabhushi A, Delisi C, Ganesan S, Bhanot G, Liou LS (2010) Identification of a microRNA panel for clearcell kidney cancer. Urology 75(4): 835-841

Jung M, Mollenkopf HJ, Grimm C, Wagner I, Albrecht M, Waller T, Pilarsky C, Johannsen M, Stephan C, Lehrach H, Nietfeld W, Rudel T, Jung K, Kristiansen G (2009) MicroRNA profiling of clear cell renal cell cancer identifies a robust signature to define renal malignancy. J Cell Mol Med 13(9B): $3918-3928$

Korpal M, Kang Y (2008) The emerging role of miR-200 family of microRNAs in epithelial-mesenchymal transition and cancer metastasis. RNA Biol 5(3): 115-119

Le XF, Merchant O, Bast RC, Calin GA (2010) The roles of MicroRNAs in the cancer invasion-metastasis cascade. Cancer Microenviron 3(1): $137-147$

Malzkorn B, Wolter M, Liesenberg F, Grzendowski M, Stuhler K, Meyer HE, Reifenberger G (2010) Identification and functional characterization of microRNAs involved in the malignant progression of gliomas. Brain Pathol 20(3): 539-550

Metias SM, lianidou E, Yousef GM (2009) MicroRNAs in clinical oncology: at the crossroads between promises and problems. J Clin Pathol 62(9): $771-776$

Motzer RJ, Bander NH, Nanus DM (1996) Renal-cell carcinoma. N Engl J Med 335(12): $865-875$

Nakada C, Matsuura K, Tsukamoto Y, Tanigawa M, Yoshimoto T, Narimatsu T, Nguyen LT, Hijiya N, Uchida T, Sato F, Mimata H, Seto M, Moriyama M (2008) Genome-wide microRNA expression profiling in renal cell carcinoma: significant down-regulation of miR141 and miR-200c. J Pathol 216(4): 418-427
Neal CS, Michael MZ, Rawlings LH, Van der Hoek MB, Gleadle JM (2010) The VHL-dependent regulation of microRNAs in renal cancer. BMC Med 8: 64

Park SM, Gaur AB, Lengyel E, Peter ME (2008) The miR-200 family determines the epithelial phenotype of cancer cells by targeting the E-cadherin repressors ZEB1 and ZEB2. Genes Dev 22(7): 894-907

Roth C, Rack B, Muller V, Janni W, Pantel K, Schwarzenbach H (2010) Circulating microRNAs as blood-based markers for patients with primary and metastatic breast cancer. Breast Cancer Res 12(6): R90

Schaefer A, Jung M, Kristiansen G, Lein M, Schrader M, Miller K, Stephan C, Jung K (2010a) MicroRNAs and cancer: current state and future perspectives in urologic oncology. Urol Oncol 28(1): 4-13

Schaefer A, Stephan C, Busch J, Yousef GM, Jung K (2010b) Diagnostic, prognostic and therapeutic implications of microRNAs in urologic tumors. Nat Rev Urol 7(5): 286-297

Schimanski CC, Frerichs K, Rahman F, Berger M, Lang H, Galle PR, Moehler M, Gockel I (2009) High miR-196a levels promote the oncogenic phenotype of colorectal cancer cells. World J Gastroenterol 15(17): 2089-2096

Sethupathy P, Megraw M, Hatzigeorgiou AG (2006) A guide through present computational approaches for the identification of mammalian microRNA targets. Nat Methods 3(11): 881-886

Sotiropoulou G, Pampalakis G, lianidou E, Mourelatos Z (2009) Emerging roles of microRNAs as molecular switches in the integrated circuit of the cancer cell. RNA 15(8): 1443-1461

Tsui KH, Shvarts O, Smith RB, Figlin RA, deKernion JB, Belldegrun A (2000) Prognostic indicators for renal cell carcinoma: a multivariate analysis of 643 patients using the revised 1997 TNM staging criteria. J Urol 163(4): $1090-1095$

Wang B, Herman-Edelstein M, Koh P, Burns W, Jandeleit-Dahm K, Watson A, Saleem M, Goodall GJ, Twigg SM, Cooper ME, Kantharidis P (2010) E-cadherin expression is regulated by miR-192/215 by a mechanism that is independent of the profibrotic effects of transforming growth factorbeta. Diabetes 59(7): $1794-1802$

White NM, Bao TT, Grigull J, Youssef YM, Girgis A, Diamandis M, Fatoohi E, Metias M, Honey RJ, Stewart R, Pace K, Bjarnason GA, Yousef GM (2011a) MiRNA profiling in clear cell renal cell carcinoma: biomarker discovery and the identification of potential controls and consequences of miRNA dysregulation. J Urol 186: $1077-1083$

White NM, Bui A, Mejia-Guerrero S, Chao J, Soosaipillai A, Youssef Y, Mankaruos M, Honey RJ, Stewart R, Pace KT, Sugar L, Diamandis EP, Dore J, Yousef GM (2010a) Dysregulation of kallikrein-related peptidases in renal cell carcinoma: potential targets of miRNAs. Biol Chem 391(4): $411-423$

White NM, Chow TF, Mejia-Guerrero S, Diamandis M, Rofael Y, Faragalla H, Mankaruous M, Gabril M, Girgis A, Yousef GM (2010b) Three dysregulated miRNAs control kallikrein 10 expression and cell proliferation in ovarian cancer. Br J Cancer 102(8): 1244-1253

White NM, Fatoohi E, Metias M, Jung K, Stephan C, Yousef GM (2011b) Metastamirs: a stepping stone towards improved cancer management. Nat Rev Clin Oncol 8(2): $75-84$

White NM, Yousef GM (2010) MicroRNAs: exploring a new dimension in the pathogenesis of kidney cancer. BMC Med 8(1): 65

Xiao F, Zuo Z, Cai G, Kang S, Gao X, Li T (2009) miRecords: an integrated resource for microRNA-target interactions. Nucleic Acids Res 37(Database issue): D105-D110

Youssef Y, White NM, Grigull J, Krizova A, Samy C, Mejia-Guerrero S, Evans A, Jewett M, Yousef GM (2011) MiRNA profiling in kidney cancer subtypes: Accurate molecular classification and correlation with cytogenetic and mRNA data identifies unique and shared biological pathways. Eur Urol 59(5): 721-730

Zhang H, Li Y, Lai M (2010) The microRNA network and tumor metastasis. Oncogene 29(7): $937-948$

This work is published under the standard license to publish agreement. After 12 months the work will become freely available and the license terms will switch to a Creative Commons Attribution-NonCommercial-Share Alike 3.0 Unported License. 